\title{
Perspectives of Students in Thailand on the Use of Humor in University Classroom
}

\author{
Henzel Embalzado ${ }^{1} \&$ Pair Sajampun ${ }^{1}$ \\ ${ }^{1}$ Assumption University of Thailand, Thailand \\ Correspondence: Henzel Embalzado, Martin de Tours School of Management and Economics, Assumption \\ University of Thailand, Bang Na Trad Road, Km. 26, Samut Prakan, Thailand.
}

Received: October 28, 2019

Accepted: December 27, 2019

Online Published: February 27, 2020

doi:10.5539/ies.v13n4p17

URL: https://doi.org/10.5539/ies.v13n4p17

\begin{abstract}
Humor is a serious business. This study explores the perception of students in Thailand on the use of humor in business classrooms indicating that humorous classroom brings about physiological and emotional benefits to students as it relieves tension and stress, makes the classroom atmosphere more comfortable and less intimidating, and facilitates better teacher-student relationship. Around 358 students from a business school in Thailand were surveyed and the results found that most of the students prefer to have certain degree of humor in classroom as opposed to the general contention that Thai classrooms should command decorum and order. This instigates a welcome shift as Thailand prepares for the full implementation of Thailand 4.0 and the education sector is looking for ways into which classrooms could facilitate a more participatory, conducive and creative learning settings. Further discussion of the results and recommendations for future study are presented in the paper.
\end{abstract}

Keywords: humor, university, business school, Thailand

\section{Introduction}

Humor has always been regarded to bring certain physiological and emotional benefits to people as those who laugh and who laugh constantly experience better well-being (Check, 1997; Ocon, 2015). But humor applied in university classroom setting has not been given considerable attention because for most part, college instructors are not professional comedians (Deiter, 2000) and teaching is a serious business (Appleby, 2018). Researches on teaching methodologies and techniques unanimously agreed that there is a lack of acknowledgement on the use of humor as a prescribed teaching tool similar to role plays, case studies, presentations and projects (Jose \& Jabamoney, 2015; Deiter, 2000; Poirier \& Wilhelm, 2014; Meksophawannagul, 2015). Others consider the lack of humorous skills on the part of the teacher as the factor why humor is not strategically applied in teaching (Deiter, 2000; Poirier \& Wilhelm, 2014; Zundel, 2018).

To deter these claims, numerous researches have proven that classes, which strategically use humor as a teaching technique facilitate better learning and class attention (Jeder, 2015). Humor helps in learning difficult materials (Aboudan, 2009), reduces anxiety (Zundel, 2018; Poirier \& Wilhelm, 2014; Benjelloun, 2009) as it creates comfortable learning environment (McCabe, Sprute, \& Underdown, 2017; Deiter, 2000) and increases students' motivation to come to class and study (Benjelloun, 2009; Zundel, 2018; Deiter, 2000). Humor also enhances retention and memory, improves problem solving skills (Poirier \& Wilhelm, 2014) and increases concentration level (Aboudan, 2009). Humorous teachers are also seen to be credible (Poirier \& Wilhelm, 2014), approachable and not intimidating (Deiter; 2000; Appleby, 2018). This helps reduce the barriers between teachers and students (Aboudan, 2009; McCabe, Sprute, \& Underdown, 2017; Jeder, 2015) thereby creating a more conducive and enjoyable classroom environment (Deiter, 2000; Benjelloun, 2009).

A humorous classroom, however, needs not to be filled with raucous laughter, and the teacher, himself need not to be unnaturally funny in order to draw out laughter in the class. Taken as a type of teaching methodology, humor can be designed just like any other teaching methodologies currently used in classrooms nowadays. Humor could be through the form of visual aids such as funny video clips, pictures and comic strips (Appleby, 2018; Deiter, 2000), lecture contents in the form of funny stories and anecdotes (Poirier \& Wilhelm, 2014), class activities such as case studies, role play, games and quiz shows (Appleby, 2018), and group discussions by way of drawing out funny experiences from students (Stambor, 2006; Klein \& Moriarty, 2017). However, all of these materials should be related to the lessons in the class and should be used in accordance to the subject's learning objectives. If not, 
some researchers warned that humor brings about undesirable consequences such as learning distractions (Zundel, 2018) and offensive regard especially if the humor is directed to malign and embarrass a student (Appleby, 2018; Poirier \& Wilhelm, 2014). Thus, necessary precaution is suggested when using humor in the classroom (Jeder, 2015; Deiter, 2000).

In Thailand, humor is not considered as a conventional teaching methodology as Thai classrooms typically command decorum and respect toward the teacher. Literature reviews about the use of humor in classrooms in Thailand only yield studies related to English teaching (Meksophawannagul, 2015), learning English as foreign language (Jaroenkitboworn, 2015; Forman, 2011) and linguistic (Wangsomchok, 2016). No other studies have been conducted on the use of humor in university most especially in the business field. Some of the studies on humor were conducted in pharmaceutical field (Poirier \& Wilhelm, 2014), medicine (Zundel, 2018) and nursing science (Dossey \& Keegan, 2008) but these are not in Thai context. To the best of the researchers' knowledge, this present study is the first ever to explore the use of humor in university classroom setting in Thailand most specifically in a Thai business school.

Business schools have always been reputed as highly stressful for students as demands for creativity, innovativeness, accuracy in computing, forecasting of trends, analyzing data and presenting results require relevant skills (Abraham et al., 2014; Patrick, Rizal, Hee, Mahadi, \& Kamarudin, 2019). According to Benjelloun (2009), most business students found business courses to be tough and tedious. Therefore, he suggested that a degree of humor in the class may help alleviate these conditions, and for students to experience less pressure and intimidation. From among the major courses in business school, Benjelloun (2009) singled out accounting and finance to be the ones having the most pressure because of the nature of their fields. However, finance students prefer the use of humor in classroom as it makes their learning not boring and taxing. But accounting students did not feel the same was as they prefer less humorous classroom atmosphere. Although the difference may not be that significant, Benjelloun (2009) theorized that this could be a validation that accounting is rigorous and tough course, and it needs certain degree of seriousness in learning. As to the other business major fields, most of the students agreed that having a certain degree of humor is helpful as it allows them pay attention to the class (Benjelloun, 2009).

This present study aims to find out the perspectives of students in Thailand on the use of humor in university classrooms. It seeks to answer two main questions: 1) What is the level of agreement of the students in Thailand on the use of humor in university classroom? and 2) Is there a significant difference on the level of agreement of students in Thailand on the use of humor in university classroom when grouped by major? This study aims to provide avenue for teachers in business school to design and adapt humorous teaching methods once proven that it is largely preferred by students. A corresponding training is in the offing to guide teachers on how to strategically and properly use humor in business classrooms.

\section{Literature Review}

\subsection{Benefits of Humor}

The apparent benefits of humor in a person's mental, physical and psychological health have been widely researched and methodically recorded. The popular quote "laughter is the best medicine" is not a feign statement as it has been scientifically proven that people who laugh and enjoy funny jokes release more endorphins, which are the body's natural painkillers (Check, 1997); at the same time, it also increases heart rate, which allows better oxidation for the body (Check, 1997). Additionally, humor increases pain-tolerance (Mahony, Burroughs, \& Hieatt, 2001), elevates mood and lessens the symptoms of depression and anxiety related to a medical condition (Hayashi, Urayama, Hori, Sakamoto, Kawai, \& Murakami, 2007). Humor has also been considered as an effective coping mechanism (Wilkins \& Eisenbraun, 2009; Dossey \& Keegan, 2008), which was found to be associated with lower stress perception and high levels of optimism such that it brings hope and happiness (Cann \& Etzel, 2008). Moreover, Ocon (2015) mentioned that laughter relaxes muscles and reduces chronic pain, exercises the lungs and chest muscles, improves respiration and stimulates circulation.

In the classroom setting, humor is deemed beneficial to students' learning motivation and learning interest (Gorham \& Christophel, 1992; Bolkan, Griffin, \& Goodboy, 2018). It accordingly creates positive attitudes toward the learning process (Poirier \& Wilhelm, 2014, Booth-Butterfield \& Booth-Buttefield, 1991) and the instructor (Houser, Cowan, \& West, 2007). Bolkan, Griffin, and Goodboy (2018) explained that when humor is appropriate and related to the course contents, it naturally draws out positive emotion among the students, which in turn captures and holds their attention and aids in increasing their ability to process instructional messages. In other words, humor used in the class brings about many educational and learning benefits as long as it is done in good taste and confined within the boundaries of the lessons that the students are learning (Jeder, 2015, Zundel, 2018). 


\subsection{Theories on Humor}

Humor has been widely studied in the realms of medicine and physical health (Wilkins \& Eisenbraun, 2009; Zundel, 2018; Dossey \& Keegan) and in the classroom setting (Deiter, 2000; Aboudan, 2009; Benejlloun, 2009) although in the latter, it is usually among children (e.g. McCabe, Sprute, \& Underdown, 2017) and in language courses (e.g. Meksophawannagul, 2015; Jaroenkitboworn, 2015; Forman, 2011; Wangsomchok, 2016). But why humor matters? Three main theories of humor are reviewed hereunder as well as a review on some psychological theories of learning and teaching.

\subsubsection{Relief Theory}

This theory posits that people laugh because it brings about reduced feeling of stress. When a person laughs, it usually results in the feeling of relief; this feeling of relief then eases tension and anxiety (Wilkins \& Eisenbraun, 2009). According to Morreal (2016), laughter releases energy from the nervous system, which is regulated by emotions. Emotions are then manifested by muscular movements that bring certain forms of behavioral reactions. But unlike other emotions, humor and laughter do not involve motivation to do anything huge or harsh such as attacking or fleeing (as with the emotions of anger, rage or fear). The relief theory contends that the movements of laughter merely release the nervous energy, which eases the person from a tense situation. In the classroom setting, cracking funny jokes that induce laughter may bring relief to students while learning a difficult material (Aboudan, 2009) or facing an intimidating situation (Poirier \& Wilhelm, 2014). Humorous classroom also creates positive perceptions towards the instructors such that they are always regarded to be sociable, approachable (Houser, Cowan, \& West, 2007) and credible (Poirier \& Wilhelm, 2014). McCabe, Sprute, and Underdown (2017) explained that teachers who use humor as their teaching approach creates a comfortable classroom that aids students' motivation and attention (Benjelloun, 2009; Zundel, 2018; Shatz \& Coil, 2008). However, in terms of answering tests, laughter has not been found to affect test scores as Bolkan, Griffin, and Goodboy (2018) discovered that integrating humor in student learning did not significantly increase their scores in various types of tests. This is potentially because integrating humor distracts students in learning core educational concepts as humorous examples could be remembered more that the lesson taught (Bolkna, Griffin, \& Goodboy, 2018). Wanzer, Frymier, and Irwin (2010) also explained that humor does not necessarily incite students' motivation to learn or increase their ability to process information since at certain times; some humor violates students' expectations and may disrupt their information processing abilities, which leads to the decrease in message retention.

\subsubsection{Incongruity Theory}

This theory assumes that laughter occurs when people perceives something that violates usual mental patterns or expectations (Morreal, 2016). In other words, people laugh at things that surprise them, but those things should not come close to be threatening or too remarkable (Wilkins \& Eisenbraun, 2009; Wanzer, Frymier, \& Irwin, 2010). The incongruity theory works on the cognitive capacity of the person. This means that the person must come to know a typical pattern of behavior and suddenly notices a difference. This difference then becomes the funny element of what he perceives. In the classroom setting, incongruity theory could be gleaned through the materials used by teachers in the class. By showing video clips that explain a lesson in a funny way may create laughter among the students. A teacher who cracks a joke about his funny experience may also be brought about by incongruous situations. Say for instance, a mathematics teacher may quip that in solving math problems, it is okay for the students to commit mistakes. By then students may perceive it as a life lesson, that everyone potentially makes mistake and it is human nature. But the teacher could say the punch line that "It is okay to make mistake because we always have the eraser to erase it!" This draws laughter in the class.

\subsubsection{Superiority Theory}

Prior to the proposition of the two previous theories mentioned above, superiority theory was initially used as the one that largely explains humor. Drawn upon the philosophical views prevalent during the eighteenth century (Morreal, 2016), superiority theory explains that we are induced into laughter because it allows us to express grander feelings to others or to the former state of ourselves. This feeling of superiority is cleverly demonstrated among comedy actors, which surpass impossible situations in a given scene (Morreal, 2016; Wilkins \& Eisenbraun, 2009). Take for instance, Charlie Chaplain trapped in a cage with a lion brings about laughter to the character, and how he escaped from the situation without being eaten alive makes it more hilarious. This feeling of superiority makes us feel happy and relieved with the situation. On the other hand, superiority theory proposes that laughter brings unity to the group (Wilkins \& Eisenbraun, 2009). This is because laughing with others brings about feeling of comfort, affiliation and cooperation. On hindsight, if laughter facilitates social bonding, it could be assumed that laughter also increases people's likeability factor. In the study by Reysen (2006), people who were 
laughing in photographs and video clips were rated as more likeable that those who did not. This means that feeling of superiority over situations, individuals and to self, as long as it is done in good taste, induce certain degree of humor. This notion has been demonstrated in studies of humor used in classroom. Houser, Cowan, and West (2007) contended that humorous teachers are perceived by students as sociable and credible (Poirier \& Wilhelm, 2014), which make students develop positive regard towards them (Gorham \& Christophel, 1990). In other words, teachers who use humor as a teaching method creates a conducive classroom (Deiter, 2000; Benjelloun, 2009) that significantly reduces the gap between teachers and students (Aboudan, 2009; McCabe, Sprute, \& Underdown, 2017; Jeder, 2015). This theory also supports the notion that the social bond formed by students because of humorous classroom allows them to interact, participate and feel less intimidated by each other (Gunawan, 2016).

\subsection{Teaching and Learning Theories}

A review on the psychological theories of teaching and learning have directed this present study towards the social learning theory of Bandura (1977) and the socio-cultural theory of learning of Lev Vygostsky (Ivic, 1994). Both theorists are firm believers of learning as a product of the learner's interaction with his environment and instructors, and not merely through the presentation of reward and reinforcement. In his original paper, Bandura (1977) opined that social learning theory considers modeling as an important element in the facilitation of a learning behavior as it allows the acquisition of symbolic representations of the learned materials on the part of the learner. For Bandura, a learner cannot absorb any learning material if he does not pay attention to it, thus attentional processes is an important function in the social context of learning. As previously mentioned, humor in the classroom undoubtedly draws attention of the students (Jeder, 2015); it accordingly facilitates a more interactive and participatory learning approach as students feel less intimidated by the learning atmosphere (McCabe, Sprute \& Underdown, 2017; Deiter, 2000). To borrow Bandura postulations about a socially interactive classroom, a humorous classroom certainly creates a more attention-driven class and in so doing, initiates better learning experiences for the students. On the other hand, mentors and instructors also play an important role in this learning process (Poirier \& Wilhelm, 2014). As Vygotsky contended, mediation is essential in the social context of learning because the presence of mediating agents such as the teachers or mentors, stimulate the development of students' higher mental processing (Kozulin, 2003). Vygotsky's concept of Zone of Proximal Development (ZPD) and scaffolding illustrate that the presence of a more knowledgeable one brings the learning process to a better core (Shabani, Khatib, \& Ebadi, 2010; Ivic, 1994). In other words, instructors that carry a certain degree of wholesome humor in the class categorically aid students to have a better learning experience as they command better attention and sound regard to the learning process. Additionally, in Vygotsky's point of view, students can learn better if they acquire the learning materials at their own pace and through their own individual capacities (Kozulin, 2003). This could be fittingly achieved if teachers are open-minded, approachable and less intimidating (Deiter, 2000; Appleby, 2018).

A newer theory on humor proposed by Wanzer, Frymier, and Irwin (2010) called Instructional Humor Processing Theory (IHPT) elaborates yet solidifies these claims. IHPT also recognizes the instrumental role of the instructor in the learning process. In their view, the instructor's use of humor should revolve around the given topic so that it facilitates a more meaningful uptake from the students. This means that humorous message in the classroom must initially be processed cognitively by the students in order for them to understand its humorous content; it is only by recognizing and understanding the humorous message that students will form the proper motivation to process the information further. This will then practically aid the students in learning the material as those students who understood the message will likely remember the lessons and in so doing, feel motivated to further engage in the learning process (Wanzer \& Frymier, 2010).

\subsection{Humor in Thai Education Context}

Humor is not prevalent in Thai classroom. As previously indicated, researches on humor in Thai classrooms were only limited within the English language learning and linguistics (e.g. Meksophawannagul, 2015; Jaroenkitboworn, 2015; Forman, 2011; Wangsomchok, 2016) and these were mainly in elementary and high school levels. Most of the university classrooms are confined within the traditional teaching pedagogy where students have to learn materials as a preparation for examinations or any types of test. It is almost a norm where a single class session is strained with chapters full of contents just to cover lessons that would likely come out in the exam. This inhibits most of the teachers to incorporate more lively teaching methodologies and be creative in their approaches as time demands more quantity than quality. However, this doesn't practically mean that other classes haven't been creative and innovative. There have been attempts of making classrooms more interactive, dynamic and fun yet, humor has not been so considered as a form of a teaching strategy.

According to Rhein (2017), many Thai teachers and students prefer rote learning, where lessons are given, and 
students are directed to answer correctly in tests. This has been the system as culturally Thai classrooms are stringent in following orders from teachers. The Thai proverb "Phu yai arb nam ron ma kon" reflects that children have to follow their elders as they come before them in the world. The term "kreng jai" signifies the respect younger people hold towards the seniors, which usually prompts them not to perform acts that go against the norm (Gunawan, 2016). The culture of "sia na" or lose face hinders Thai people to get involve in confrontation or discussion as they avoid making themselves look bad (Stainton, 2017). In classroom setting, it is evident that students do not actively participate in class discussions such as asking questions or answering questions as they do not want to be embarrassed in front of others. The terms "Ajarn" or "Kru," which means professor or teacher are used to regard respect to teachers when talking or dealing with them (Gunawan, 2016).

These cultural milieus potentially explain why humor or humorous classrooms are not prevalent in Thai education context because there is supposed to be a certain degree of command and respect between teachers and students (Rhein, 2017). As Hofstede (2011) indicated, Thailand shows high levels of power distance, collectivism, femininity and uncertainty avoidance, which means that the gap between teachers and students are clearly distinguishable such that students are less likely to confront their teachers (Rhein, 2017; Gunawan, 2016). In so doing, the collectivistic and femininity cultures put forth Thai people's meekness and politeness when dealing with others; they prefer to stay in the group, have harmonious working relationship with them and avoid performing behaviors that make them stand out (Rhein, 2017; Gunawan, 2016). In the same vein, uncertainty avoidance is a cultural trait that Thais have a strong connection with. This indicates that in the classroom setting, Thai students prefer structured learning situations, scheduled activities and strict timetables. They usually feel threatened by ambiguous situations and typically avoid challenges. As a result, they rather follow and carry out instructions given by teachers and avoid disagreeing with them (Gunawan, 2016). These cultural factors may have prohibited the formal inclusion of humor in Thai classroom as being more serious and structured are preferred than having a more informal classroom set-up.

The need for a more inclusive, participative and dynamic classroom has been stressed in many position papers regarding the current Thai education system (see Wittayasin, 2017; Rhein, 2017). As Thailand is gearing towards the full implementation of Thailand 4.0, researchers and scholars suggested for education reform (Wittayasin, 2017) that will help shift the focus of teaching and learning to a more flexible, creative and innovative classroom (Wattanavoorakijkul, 2019) that allows students to be more collaborative and participative in their learning activities (Rhein, 2017; Xu \& Chuaychoowong, 2017). As Wittayasin (2017) has emphasized, developing the twenty-first century skills of Thai students such as their creativity and critical thinking skills, literacy on information and technology and leadership abilities (Saavedra \& Opfer, 2012; Dede, 2009) could be attained by finding new teaching approaches and learning styles. Rhein (2017) has suggested that finding a balance among cultural traditions, western knowledge and global citizenship provides a new pedagogical paradigm to the educational system in Thailand. Hence, bringing forth a more conducive classroom that is handled by less intimidating teachers and more dynamic learning activities may help realize these objectives. By using humor strategically as a teaching tool, it may aid teachers to imbue active participation among the students, stimulating their creative imagination and innovative spirit. After all, as Gunawan (2016) put it, "learning while having fun approach can be effective for most Thai students (p. 160)."

\section{Methodology}

This present study surveyed 358 students, who come from eleven business major courses of Assumption University of Thailand. Majority of the participants come from Marketing (22.3\%), Accounting (18.2\%) and International Business Management (IBM) (11.7\%) wherein most of them are in the fourth-year level (72\%) while some are in third year $(26 \%)$ and second year levels $(2 \%)$. About $56 \%$ are female and $44 \%$ are male whose nationalities are Thai (88\%), Chinese (4\%), Korean $(2 \%)$ and others $(6 \%)$. The participants were selected through stratified random sampling method.

A two-page questionnaire was distributed among the target participants, which contain personal information about them, and questions adapted from Benjelloun (2009), which identify the perception of the students on the use of humor in the classroom. Questions such as "Most of our professors use humor as a teaching tool," and "Humor helps to hold my attention and keeps class interesting," are evaluated through a 5-point Likert scale that range from 1 Strongly Disagree to 5 Strongly Agree. A mean percentage was computed to determine the agreement of the students on the use of humor in the classroom while one-way ANOVA was used to identify the significant difference in the students' perception by major.

\section{Results}

Firstly, reliability analysis was conducted to measure the consistency of the scale. The results revealed that 
Cronbach's alpha value for the scale was above 0.70 , which ensure the decent reliability of the measurement instrument. The average mean of the level of agreement among the students on the use of humor in classroom was computed according to each major as depicted in Table 1. Overall, the average mean of the students from all eleven majors is $4.06(\mathrm{SD}=0.46)$. As to the average mean of each major, it shows that IDM got the highest $(\mathrm{M}=4.23, \mathrm{SD}$ $=0.36)$ followed by Real Estate $(\mathrm{M}=4.22, \mathrm{SD}=0.41)$, Finance $(\mathrm{M}=4.21, \mathrm{SD}=0.47)$ and Economics $(\mathrm{M}=4.17$, $\mathrm{SD}=0.49)$, respectively; Marketing $(\mathrm{M}=4.10, \mathrm{SD}=0.50)$, $\mathrm{MIS}(\mathrm{M}=4.04, \mathrm{SD}=0.34), \mathrm{HTM}(\mathrm{M}=4.03, \mathrm{SD}=$ $0.53)$, Insurance $(\mathrm{M}=4.02, \mathrm{SD}=0.45), \mathrm{IBM}(\mathrm{M}=4.01, \mathrm{SD}=0.39)$, Management $(\mathrm{M}=3.99, \mathrm{SD}=0.46)$ and Accounting $(\mathrm{M}=3.92, \mathrm{SD}=0.43)$ followed suit.

Table 1. Descriptive results

\begin{tabular}{|c|c|c|c|c|c|c|c|c|}
\hline \multicolumn{9}{|c|}{ Mean of Students' Perception of the Use of Humor in the Classroom } \\
\hline & \multirow{4}{*}{$\mathrm{N}$} & \multirow{4}{*}{ Mean } & \multirow{4}{*}{$\begin{array}{c}\text { Std. } \\
\text { Deviation }\end{array}$} & \multirow{4}{*}{ Std. Error } & \multirow{2}{*}{\multicolumn{2}{|c|}{$\begin{array}{l}95 \% \text { Confidence Interval for } \\
\text { Mean }\end{array}$}} & \multirow{4}{*}{ Minimum } & \multirow{4}{*}{ Maximum } \\
\hline & & & & & & & & \\
\hline & & & & & \multirow{2}{*}{ Lower Bound } & \multirow{2}{*}{$\begin{array}{l}\text { Upper } \\
\text { Bound }\end{array}$} & & \\
\hline & & & & & & & & \\
\hline Marketing & 80 & 4.1037 & .50150 & .05607 & 3.9921 & 4.2154 & 2.50 & 5.00 \\
\hline Management & 37 & 3.9946 & .46960 & .07720 & 3.8380 & 4.1512 & 2.70 & 4.80 \\
\hline Accounting & 65 & 3.9277 & .43139 & .05351 & 3.8208 & 4.0346 & 2.90 & 4.80 \\
\hline IBM & 42 & 4.0190 & .39647 & .06118 & 3.8955 & 4.1426 & 3.30 & 4.90 \\
\hline Finance & 28 & 4.2179 & .47614 & .08998 & 4.0332 & 4.4025 & 3.20 & 4.90 \\
\hline Insurance & 5 & 4.0200 & .45497 & .20347 & 3.4551 & 4.5849 & 3.50 & 4.70 \\
\hline Real Estate & 19 & 4.2211 & .41443 & .09508 & 4.0213 & 4.4208 & 3.40 & 5.00 \\
\hline Economics & 18 & 4.1778 & .49652 & .11703 & 3.9309 & 4.4247 & 3.10 & 4.80 \\
\hline HTM & 33 & 4.0364 & .53492 & .09312 & 3.8467 & 4.2260 & 2.50 & 4.70 \\
\hline MIS & 9 & 4.0444 & .34681 & .11560 & 3.7779 & 4.3110 & 3.40 & 4.40 \\
\hline IDM & 22 & 4.2364 & .36456 & .07772 & 4.0747 & 4.3980 & 3.10 & 4.70 \\
\hline Total & 358 & 4.0687 & .46427 & .02454 & 4.0205 & 4.1170 & 2.50 & 5.00 \\
\hline
\end{tabular}

The differences of students' perception of the use of humor in the classroom were then computed as reported in the one-way ANOVA results in Table 2.

Table 2. ANOVA results

Table 3. ANOVA

\begin{tabular}{|c|c|c|c|}
\hline \multicolumn{4}{|c|}{ Test of Homogeneity of Variances } \\
\hline \multicolumn{4}{|c|}{$\begin{array}{l}\text { Mean of Students' Perception of the Use of Humor in } \\
\text { the Classroom }\end{array}$} \\
\hline $\begin{array}{l}\text { Levene } \\
\text { Statistic }\end{array}$ & df1 & df 2 & Sig. \\
\hline .782 & 10 & 347 & .646 \\
\hline
\end{tabular}

\begin{tabular}{|c|c|c|c|c|c|}
\hline \multicolumn{6}{|c|}{ Mean of Students'Perception of the Use of Humor in the Classroom } \\
\hline & $\begin{array}{l}\text { Sum of } \\
\text { Squares }\end{array}$ & df & Mean Square & $\mathrm{F}$ & Sig. \\
\hline Between Groups & 3.646 & 10 & .365 & 1.726 & .074 \\
\hline Within Groups & 73.304 & 347 & .211 & & \\
\hline Total & 76.950 & 357 & & & \\
\hline
\end{tabular}

Note. A significance level of 0.05 .

The result of the one-way ANOVA showed no significant difference in terms of the perception students on the use of humor in the classroom as grouped by major. The result was placed at $F(10,374)=1.72, p=.074$, which signified no differences.

\section{Discussion}

Given the overall results, it indicates that the students have a quite positive perception on the use of humor in the 
classroom. This means that students find humorous classrooms to be interesting and fun, which help them feel relieved from tensions and stresses. Students feel more comfortable in participating in class discussions and activities when the class atmosphere possesses certain degree of humor as it seemingly creates a positive classroom environment. As mentioned by McCabe, Sprute, and Underdown (2017), comfortable learning environment allows learners to feel less intimidated with the learning material, and it accordingly facilitates a more interactive teacher-student relationship. The use of humor as a teaching tool helps students keep their attention to the class, and sometimes aids in the retention of difficult learning materials (Aboudan, 2009).

From among the majors surveyed, it is notable that Industrial Management (IDM), Real Estate, Finance and Marketing gathered the highest agreement while Management and Accounting got the lowest. This is reflective to the findings of Benjelloun (2009) where Finance major students preferred to have a humorous classroom while Accounting did not. This is most probably because the nature of Accounting as a field requires thorough analysis and utmost precision in the performance of their work while Finance on the other hand, is intricate and boring, thus they need certain degree of humor in dealing with their cases. The majors of IDM, Real Estate and Marketing are all directly involved with business processes that certainly require creativity, sharpness and eloquence thus, the use of humor is somehow preferred as it brightens up their mood, allows them to think creatively and become more adept with the learning material. Management happens to prefer less humorous classes as leading and managing business organizations may not be a laughing matter.

However, the not significant differences in terms of the students' perception on the use of humor in the classroom as categorized by major indicate that overall, the students prefer to have certain degree of humor in their classroom learning experiences. This is in some ways going against the Thai tradition of classrooms being more structured and stringent, and teachers act as managers rather than mentors (Rhein, 2017; Gunawan, 2016). Perhaps the anticipation of the educational reform in accordance with Thailand 4.0 makes this idea of a more participatory, inclusive and humorous classroom more preferable as it facilitates the enhancement and inculcation of twenty-first century skills (Wittayasin, 2017; Saavedra \& Opfer, 2012) among the students not to mention the physiological and emotional benefits it brings to each individual student. The proper use of humor as teaching tool may provide greater opportunities for students to freely express themselves, become more creative and develop more innovative ideas.

\section{Recommendation and Future Study}

Considering the preference of students and the apparent benefits of using humor in the classroom, a structured training on the use of humor as a teaching technique could be beneficial for both teachers and students. Given the fact that humor is not commonly used as teaching methodology especially in Thailand due to norms and cultural restrictions, exploring more on the proper and effective usage of humor as a teaching tool will promote positive and productive classroom environment in Thai context.

This research does not only provide theoretical contributions but also practical implications. Since the study on the use of humor in Thai universities especially in business field has never been conducted before, this landmark study reveals preliminary insights about the perception of students in Thailand on the use of humor in classroom. This paves way to a further exploration of the context of humor in various academic settings. It is also ideal that other academic courses such as communication, engineering, architecture, nursing and medical fields and social sciences will be surveyed about their students' preferences on the use of humor so as to further validate this present study's claim. Furthermore, cross-cultural investigation that involves students from different cultures will also be helpful in understanding the effects of culture on the use of humor in the academic setting. On the practical side, the findings of this study provide educators in higher education institutions to propose and conduct trainings on the proper use of humor as teaching technique as it has been shown to be preferred by most students as it instigates a more conducive, creative and innovative classroom environment. Concerned government sector may also take a cue from this study's findings to introduce educational reform in order to face the challenges of the future more effectively.

Lastly, this present study also lays the possibility of conducting experimental research to determine the effects of humor on the students' learning outcome. As this study only revolves around the perception and preferences of students on the use of humor in the class, it is also ideal to identify whether humor has an effect in memory recall, retention and academic scores.

\section{References}

Aboudan, R. (2009) Laugh and learn: Humor and learning a second language. International Journal of Arts and Sciences, 3(3), 90-99. 
Abraham, R. R., Hande, V., Sharma, M. E. J., Wohlrath, S. K., Keet, C. C., \& Ravi, S. (2014). Use of humour in classroom teaching: Students' perspectives. Thrita, 3(2), 1-4. https://doi.org/10.5812/thrita.10517

Appleby, D. C. (2018). Using humor in the college classroom: The pros and cons. Psychology Teacher Network.

Bandura, A. (1977). Social Learning Theory. New York: General Learning Press.

Benjelloun, H. (2009). An empirical investigation of the use of humor in university classrooms. Education, Business and Society: Contemporary Middle Eastern Issues, 2(4), 312-322. https://doi.org/10.1108/17537980911001134

Bolkan, S., Griffin, D. J., \& Goodboy, A. K. (2018). Humor in the classroom: The effects of integrated humor on $\begin{array}{lllll}\text { student learning. } & \text { Communication }\end{array}$ https://doi.org/10.1080/03634523.2017.1413199

Booth-Butterfield, S., \& Booth-Butterfield, M. (1991). Individual differences in the communication of humorous messages. Southern Communication Journal, 56, 205-221. https://doi.org/10.1080/10417949109372831

Buchowski, M., Majchrzak, K., Blomquist, K., Chen, K., Byrne, D., \& Bachorowski, J. (2007). Energy expenditure of genuine laughter. International Journal of Obesity, 31, 131-137. https://doi.org/10.1038/sj.ijo.0803353

Cann, A., \& Etzel, K. (2008). Remembering and anticipating stressors: positive personality mediates the relationship with sense of humor. Humor, 21(2), 157-178. https://doi.org/10.1515/HUMOR.2008.008

Check, J. (1997). Humor in education. Physical Educator, 54(3), 165-167. https://doi.org/10.1023/A:1017122230464

Dede, C. (2010). Comparing frameworks for 21st century skills. 21st century skills: Rethinking how students learn, 20, 51-76.

Deiter, R. (2000). The use of humor as a teaching tool in the college classroom. NACTA Journal, 4(2), 20-28

Dossey, B., \& Keegan, L. (2008). Holistic Nursing. Boston, MA: Jones \& Bartlett.

Forman, R. (2011). Humorous language play in a Thai EFL classroom. Applied Linguistics, 32(5), 541-565. https://doi.org/10.1093/applin/amr022

Galloway, G., \& Cropley, A. (1999). Benefits of humor for mental health: Empirical findings and direction for further research. Humor, 12(3), 301-314. https://doi.org/10.1515/humr.1999.12.3.301

Gorham, J., \& Christophel, D. (1992). Students' Perception of Teacher Behaviors as Motivating and Demotivating Factors in College Classes. Communication Quarterly, 40, 239-252. https://doi.org/10.1080/01463379209369839

Gunawan, J. (2016). Understanding culture in higher education in Thailand. Education for Health, 29, 160-161. https://doi.org/10.4103/1357-6283.188783

Hayashi, T., Urayama, O., Hori, M., Sakamoto, S., Kawai, U., \& Murakami, K. (2007). Laughter modulates prorenin receptor gene expression in patients with type 2 diabetes. Journal of Psychosomatic Research. 62(6), 703-706. https://doi.org/10.1016/j.jpsychores.2007.01.010

Hoffman, M. (2013). Benefits of humor and laughter: A brief introduction for rehabilitation counselors. OpenSIUC.

Hofstede, G. (2011). Dimensionalizing cultures: The Hofstede model in context. Online readings in psychology and culture, 2(1), 8. https://doi.org/10.9707/2307-0919.1014

Houser, M., Cowan, R., \& West, D. (2007). Investigating a new education frontier: Instructor communication behavior in CD-ROM texts-Do traditionally positive behaviors translate into this new environment? Communication Quarterly, 55(1), 19-38. https://doi.org/10.1080/01463370600998319

Ivic, I. (1994). Lev S. Vygotsky. Prospects: the quarterly review of comparative education, 24(3/4), 471-485. https://doi.org/10.1007/BF02195302

Jaroenkitboworn, K. (2015). Failed L2 humor: A case study of EFL Thai learners. Proceedings of the 5th Humor Research Conference, Texas A\&M University-Commerce, 20-22 February 2015.

Jeder, D. (2015). Implications of using humor in the classroom. Procedia-Social and Behavioral Sciences, 180, 828-833. https://doi.org/10.1016/j.sbspro.2015.02.218

Jose, F. T. \& Jabamoney, S. (2015). Effective teaching with humor. Proceedings of ISERD International 
Conference, Bangkok, Thailand. 16th May 2015. (pp. 61-63).

Kozulin, A. (2003). Psychological tools and mediated learning. In A. Kozulin, B. Gindis, V. Ageyev, \& S. Miller (Eds.), Vygotsky's Educational Theory in Cultural Context (pp. 15-38). New York: Cambridge University Press. https://doi.org/10.1017/CBO9780511840975.003

Liu, Y., Sun, L., Wu, X., Yang, Y., Zhang, C., Zhou, H. \& Quan, X. (2017). Use of humor in medical education: A survey of students and teachers at a medical school in China. BMJ Open, 7, e018853. https://doi.org/10.1136/bmjopen-2017-018853

Louie, D., Brook, K., \& Frates, E. (2016). The laughter prescription: A tool for lifestyle medicine. American journal of lifestyle medicine, 10(4), 262-267.https://doi.org/10.1177/1559827614550279

Mahony, D., Burroughs W., \& Hiert, A. (2001). The effects of laughter on discomfort threshold: Does expectations become reality? Journal General Psychology, 128(2), 217-226. https://doi.org/10.1080/00221300109598909

Makewa, L., Role, E., \& Genga, J. (2011). Teachers' use of humor in teaching and students' rating of their effectiveness. International Journal of Education, 2(2), 1-17. https://doi.org/10.5296/ije.v3i2.631

McCabe, C., Sprute, K., \& Underdown, K. (2017). Laughter to learning: How humor can build relationships and increase learning in the online classroom. Journal of Instructional Research, 6, 4-7. https://doi.org/10.9743/JIR.2017.9

Meksophawannagul, M. (2015). Teacher and learner views of effective English teaching in the Thai context: The case of engineering students. English Language Teaching, 8(11), 99-116. https://doi.org/10.5539/elt.v8n11p99

Michel, A. (2017). The science of humor is no laughing matter. Association of Psychological Science.

Morreal, J. (2016). Philosophy of humor. Stanford Encyclopedia of Philosophy.

Ocon, R. (2015). Using humor to create a positive learning environment. 122nd ASEE Annual Conference and Exposition. Conference Proceeding. https://doi.org/10.18260/p.25003

Patrick, B., Rizal, A., Hee, O., Mahadi, M., \& Kamarudin, S. (2019). Factors hindering undergraduate students from starting a business while studying. International Journal of Academic Research in Business and Social Sciences, 9(1), 455-468. https://doi.org/10.6007/IJARBSS/v9-i1/5421

Poirier, T. I., \& Wilhelm, M. (2014). Use of humor to enhance learning: bull's eye or off the mark. American journal of pharmaceutical education, 78(2). https://doi.org/10.5688/ajpe78227

Reddington, E. (2015). Humor and play in language classroom interaction: A review of the literature. Columbia University Working Papers in TESOL \& Applied Linguistics, 15(2), 22-38.

Reysen, S. (2006). A new predictor of likeability: laughter. North American Journal of Psychology, 8(2), 373-382.

Rhein, D. (2017). International higher education in Thailand: Challenges within the changing context. Journal of Alternative Perspectives in Social Sciences, 8(3), 281-298.

Saavedra, A. R., \& Opfer, V. D. (2012). Learning 21st-century skills requires 21 st-century teaching. Phi Delta Kappan, 94(2), 8-13. https://doi.org/10.1177/003172171209400203

Shabani, K., Khatib, M., \& Ebadi, S. (2010). Vygotsky's Zone of Proximal Development: Instructional implications and teachers' professional development. English Language Teaching, 3(4), 237-248. https://doi.org/10.5539/elt.v3n4p237

Shatz, M., \& Coil, S. (2009). Regional campus teaching ain't a joke but humor can make it effective. Association for University Regional Campuses of Ohio, 14,105-107.

Stainton, H. (2017). Inside the Thai classroom: A stakeholder insight. The New English Teacher, 11(1), 1.

Stein, D. (2017). International higher education in Thailand: Challenges within a changing context. Journal of Alternative Perspectives in Scoial Sciences, 8(3), 281-298.

Wamsomchok, C. (2016). Linguistic strategies to express humor in Thai context. International Journal of Social Science and Humanity, 6(6), 462-465. https://doi.org/10.7763/IJSSH.2016.V6.691

Wanzer, M. B., Frymier, A. B., \& Irwin, J. (2010). An explanation of the relationship between instructor humor and student learning: Instructional humor processing theory. Communication education, 59(1), 1-18. 
https://doi.org/10.1080/03634520903367238

Wattanavorakijkul, N. (2019). Challenges faced by Thai tertiary teachers in designing and delivering English courses in the 21st century. Thaitesol Journal, 32(1), 33-54

Wilkins, J., \& Eisenbraun, A. J. (2009). Humor theories and the physiological benefits of laughter. Holistic nursing practice, 23(6), 349-354. https://doi.org/10.1097/HNP.0b013e3181bf37ad

Wittayasin, S. (2017). Education challenges to Thailand 4.0. Journal of Integrated Education Development, 2(2), 29-35.

Xu, L., \& Chuaychoowong, M. (2017). A case study of teachers' beliefs and practices with English-Medium Instruction (EMI) at Mae Fah Luang University. DRAL 3/19th ESEA 2017. Conference Proceeding.

Zamani, R., \& Ahangari, S. (2016). Characteristics of an Effective English Language Teacher (EELT) as Perceived by Learners of English. International Journal of Foreign Language Teaching \& Research, 4(14), 69-88.

Zundel, B. (2018). Humor in the classroom: The good, the bad and the ugly. Presented paper of 34th Annual Clinical Laboratory Educators' Conference, Houston, Texas.

\section{Copyrights}

Copyright for this article is retained by the author(s), with first publication rights granted to the journal.

This is an open-access article distributed under the terms and conditions of the Creative Commons Attribution license (http://creativecommons.org/licenses/by/4.0/). 